\title{
LUMBAR SPINE SURGERY. IMPORTANCE OF SAGITTAL BALANCE IN THE QUALITY OF LIFE OF PATIENTS
}

\author{
CIRURGIA DA COLUNA LOMBAR. IMPORTÂNCIA DO EQUILÍBRIO SAGITAL \\ NA QUALIDADE DE VIDA DOS PACIENTES
}

CIRUGÍA DE LA COLUMNA LUMBAR. IMPORTANCIA DEL EQUILIBRIO

SAGITAL EN LA CALIDAD DE VIDA DE LOS PACIENTES

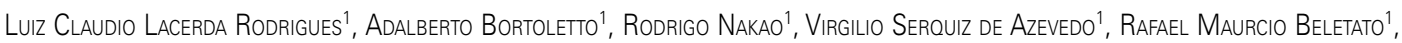 \\ Daniel Carrijo Maroues ${ }^{1}$ \\ 1. Hospital Santa Marcelina, São Paulo, SP, Brazil.
}

\begin{abstract}
Objective: To evaluate whether performing surgery in degenerative diseases of the lumbar spine modify the spinopelvic balance and influences the clinical outcome and the quality of life of patients. Methods: The spinopelvic balance was evaluated in 25 patients using plain radiographs of the lumbosacral region including the proximal femur, as well as evaluating the quality of life on two separated occasions. Results: The measure of spinopelvic balance was obtained by averaging the angles of sacral slope, pelvic version and pelvic incidence. Mean preoperative angles were $59.88^{\circ}, 22.84^{\circ}$, and $37.44^{\circ}$, respectively, and the mean postoperative values were $61.56^{\circ}, 24.64^{\circ}$, and $37.32^{\circ}$, respectively. Regarding the questionnaires on quality of life, the Oswestry index showed mean preoperative values of 46.24 , characterized as severe disability and mean postoperative values of 13.29 denoting satisfactory response after surgical treatment. The SF-36 questionnaire showed important and significant improvement in quality of life in different domains, with the exception of physical limitation and social aspects, with a p-value of 0.02 and 0.025 , respectively. Conclusion: Patients undergoing surgical treatment of degenerative lumbar diseases showed no significant changes in the spinopelvic balance, but showed significant improvement in quality of life after surgery.
\end{abstract}

Keywords: Intervertebral disc degeneration; Low back pain; Lumbosacral region; Postural balance; Quality of life.

\section{RESUMO}

Objetivo: Avaliar se a realização de procedimento cirúrgico nas doenças degenerativas da coluna lombar modifica o balanço espinopélvico e influencia os achados clínicos e a qualidade de vida dos pacientes. Métodos: O equilíbrio espinopélvico foi avaliado em 25 pacientes utilizando radiografias simples da região lombossacra, incluindo a parte proximal do fêmur, bem como a avaliação da qualidade de vida em dois momentos. Resultados: A medida do equilíbrio espinopélvico foi obtida pela média dos ângulos da inclinação sacral, versão pélvica e incidência pélvica. Os ângulos pré-operatórios médios foram $59,88^{\circ}, 22,84^{\circ}$ e $37,44^{\circ}$, respectivamente, e os valores pós-operatórios médios foram $61,56^{\circ}, 24,64^{\circ}$ e $37,32^{\circ}$, respectivamente. Com relação aos questionários sobre qualidade de vida, no índice de Oswestry obtivemos valores pré-operatórios médios de 46,24, caracterizados como incapacidade intensa e valores pós-operatórios médios de 13,29 denotando resposta satisfatória após o tratamento cirúrgico. O questionário SF-36 demonstrou melhora importante e significativa da qualidade de vida nos diferentes domínios, com exceção dos domínios de limitação física e aspectos sociais que obtiveram valor $p$ de 0,02 e 0,025, respectivamente. Conclusão: Os pacientes submetidos ao tratamento cirúrgico de doenças lombares degenerativas não apresentaram alterações significativas do equilíbrio espinopélvico, mas apresentaram melhora significativa da qualidade de vida no pós-operatório.

Descritores: Degeneração do disco intervertebral; Dor lombar; Região lombossacral; Equilíbrio postural; qualidade de vida.

\section{RESUMEN}

Objetivo: Evaluar si la realización de cirugía en las enfermedades degenerativas de la columna lumbar modifica el balance espinopélvico e influye en los resultados clínicos y la calidad de vida de los pacientes. Métodos: El equilibrio espinopélvico fue evaluado en 25 pacientes utilizando radiografías simples de la región lumbosacra, incluyendo la parte proximal del fémur, así como la calidad de vida en dos ocasiones. Resultados: La medida del equilibrio espinopélvico se obtuvo con el promedio de los ángulos del índice sacral, la variación pélvica y el índice pélvico. El promedio de los ángulos preoperatorios fue $59,88^{\circ}, 22,84^{\circ}$ e $37,44^{\circ}$, respectivamente y el promedio de los valores postoperatorios fue $61,56^{\circ}, 24,64^{\circ}$ e $37,32^{\circ}$, respectivamente. En cuanto a los cuestionarios sobre calidad de vida, en el índice de Oswestry los valores preoperatorios medios fueron 46,24, caracterizando discapacidad severa y en el postoperatorio 13,29, denotando respuesta satisfactoria después de la cirugía. El cuestionario SF-36 demostró mejora importante y significativa de la calidad de vida en los diferentes aspectos, con la excepción de los dominios de limitación física y los aspectos sociales, que obtuvieron valor p de 0,02 y 0,025, respectivamente. Conclusión: Los pacientes sometidos al tratamiento quirúrgico para enfermedades 
lumbares degenerativas no presentaron alteraciones significativas en el equilibrio espinopélvico, pero presentaron mejora significativa de la calidad de vida en el postoperatorio.

Descriptores: Degeneración del disco intervertebral; Dolor de la región lumbar; Región lumbosacra; Balance postural; Calidad de vida.

\section{INTRODUCTION}

From the earliest records known to man, low back pain was believed to be caused by the action of demons, and was only recognized as a disease by the Greeks. ${ }^{1}$

Lumbar pain has been widely studied around the world, and over time, with the evolution of science, some diseases, such as disc degeneration and lumbar stenosis, have been defined as some of its causes. ${ }^{1-3}$

Degenerative disc disease, which is present in a considerable proportion of the population, is prevalent in men aged between 20 and 60 years. It can be defined as a degenerative process affecting the intervertebral discs, which results in changes in pressure distribution in the pulposus nucleus, and can cause bulging and even rupture of the fibrous annulus. ${ }^{4}$

When people were treated, it was observed that the results were not universally successful. Complex psychosocial issues, depression, and secondary gain started to be considered, in addition to other hitherto unknown anatomical and mechanical causes, which are well-known today. ${ }^{1}$

Spinopelvic balance directly related to postural balance is now a probable prognostic factor in the conduct of the diseases of the spine, particularly degenerative disease of the lumbar spine, and takes into account the different pelvic and radiographic parameters of sagittal balance. ${ }^{5}$ It effectively provides valuable assistance for the diagnosis, prognosis and treatment of degenerative diseases of the lumbar spine. ${ }^{3}$ It is estimated that this balance may be directly or indirectly related to the appearance or worsening of pain symptoms present in the vertebral spine, and that this influence may be directly or indirectly related to overload on the joint facets and disc.

A study in which the assessment of the spinopelvic angles, and their correlation with the patients' quality of life, and a subsequent postsurgical correlation, may attempt to respond to the real importance of these angles in the clinical and surgical response of patients.

The aim of this study was to evaluate whether carrying out surgery in degenerative diseases of the lumbar spine alters the spinopelvic angles, and whether these changes influence the clinical outcome and in the quality of life of patients following surgery.

\section{PATIENTS AND METHODS}

For the calculation of the sample with a power of $80 \%$ and a level of significance of $5 \%$, when compared by the Oswestry score at 2 different time points, we arrived at a total of 25 patients (n) to validate the results.

The data were collected in the period December 1, 2012 to June 2014.

This is a prospective, controlled, non-case study, aimed at assessing the influence of lumbar spine surgery on sagittal balance of patients with lumbar diseases, and its influence on quality of life.

There are no conflicts of interest in the conducting of this study, and it was approved by the local Research Ethics Committee (REC).

Patients were included in the study by means of the following criteria: patients of both genders, aged between 18 and 70 years, diagnosed with degenerative disc disease in the lumbar segment and indicated for arthrodesis surgery with instrumentation, attended by the Orthopedics and Traumatology department of the hospital, and who agreed to participate in the study by signing the voluntary and informed consent form.

The exclusion criteria were: patients who did not agree to par- ticipate in the study, those without the necessary discernment to reply to the questionnaires, and those with traumatic diseases, spondylolisthesis and tumoral lesions in any segment of the vertebral spine, as well as those who had undergone previous surgeries related to lumbar disease.

Two questionnaires were applied for the evaluation of quality of life (Oswestry and SF-36) at two different time points: four weeks before, and four weeks after the surgical procedure, by the same evaluator. The SF-36 provided the variables: functional capacity, physical limitation, pain, general health status, vitality, social aspects, emotional aspects, and mental health.

The evaluation of sagittal spinopelvic balance was performed through the measurement of the variation in angles of pelvic version (PV), pelvic incidence (PI) and sacral slope (SI). The radiographs obtained were standardized at the imaging department of the hospital, and included images in profile of the lumbosacral spine, including the proximal femurs in the standing position. The examinations were performed during the preoperative prep and on the postoperative follow-up visit, which occurred on average four weeks after the procedure. This measurement was always made by a senior surgeon, to avoid measurement bias.

The comparison between the pre- and postoperative variables was performed using the Wilcoxon test for paired measurements. A level of $p<0.01$ was considered statistically significant.

\section{RESULTS}

All the patients met the inclusion criteria and none of the subjects included in the study were lost to follow-up.

A total of 25 patients were assessed, aged between 27 and 69 years; the mean age was 52.28 years, with a standard deviation of 9.02 years and a median of 54 years. Thirteen patients $(52.0 \%)$ were male and 12 (48.0\%) were female.

Based on the data collected by measuring the angles, we obtained mean preoperative values for pelvic incidence, pelvic variation, and sacral slope, of $59.88^{\circ} ; 22.84^{\circ}$ and $37.44^{\circ}$, respectively, and mean postoperative values of $61.56^{\circ} ; 24.64^{\circ}$ and $37.32^{\circ}$, respectively, as shown in Table 1.

The evaluation of spinopelvic balance showed the following $p$ values using the Wilcoxon Test: 0.15 for pelvic variation; 0.53 for sacral slope, and 0.42 for pelvic incidence. In all these cases, it is not possible to affirm that there are significant differences between the medians of the variables before and after surgery.

To analyze the preoperative parameters of the SF-36 quality of life questionnaire, the average results obtained were: 14.36 for functional capacity; 4.96 for physical limitation, 5.04 for pain; 14.56 for general health status; 11,96 for vitality; 6.32 for social aspects; 3.88 for emotional aspects, and 16.44 for mental health. And the postoperative parameters were: 21.40 for functional capacity, 6.08 for physical limitation; 7.24 for pain; 17,96 for general health status; 16.52 for vitality; 7.84 for social aspects; 5.6 for emotional aspects,

Table 1. Average values for the angles of sagittal spinopelvic balance.

\begin{tabular}{c|c|c|c}
\hline & Preoperative & Postoperative & P \\
\hline Pelvic Index & $59.88^{\circ}$ & $61.56^{\circ}$ & 0.42 \\
\hline Pelvic Variation & $22.84^{\circ}$ & $24.64^{\circ}$ & 0.15 \\
\hline Sacral Index & $37.44^{\circ}$ & $37.32^{\circ}$ & 0.53 \\
\hline
\end{tabular}


and 23,24 for mental health, as illustrated in Table 2.

The $p$ values obtained for the pre- and postoperative comparisons were: 0.001 for functional capacity; 0.02 for physical limitation; 0.009 for pain; 0.007 for general health status; 0.001 for vitality; 0.025 for social aspects; 0.0005 for emotional aspects, and 0.001 for mental health. With the exception of physical limitation and social aspects, all the p values were less than 1\%, demonstrating differences with a level of significance of up to $99 \%$.

For the Oswestry index, we obtained the following values: preoperative mean of $46.24 \%$ (severe incapacity), and postoperative mean of $13.29 \%$ (satisfactory), with p-value of 0.00006 , as shown in graph 1.

\section{DISCUSSION}

There is a lot of current research on the relationships between the angles of spinopelvic balance and their influence on diseases of the lumbar spine. ${ }^{6}$ Extreme angles are more closely related to lumbar diseases such as disc degeneration, spondylolisthesis and spondylolysis; however, this is not an absolute truth, as many patients with altered angles are asymptomatic., ${ }^{4,9}$

In the study in question, we correlate the values obtained for these variables with the impact on quality of life after surgical procedures. We observed that no significant changes in spinospelvic angles occurred; however, there was a significant improvement in more than one parameter in the assessment of patients' quality of life (SF-36 and Oswestry) ${ }^{10}$ which suggests that the clinical improvement is not related to changes in angles of pelvic balance,

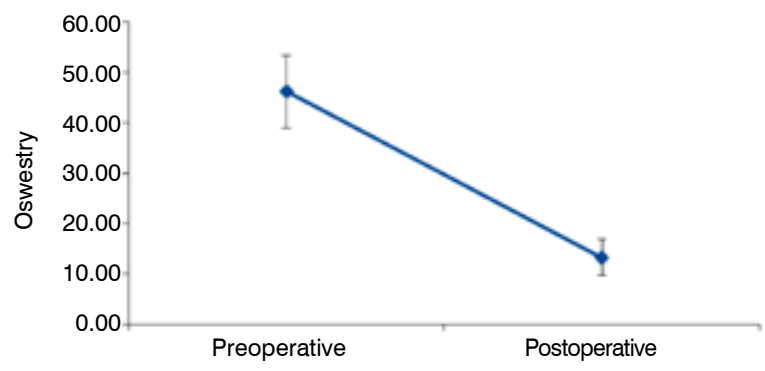

Graph 1. Average pre-and postoperative values for the Oswestry questionnaire.

Table 2. Average values of the domains of the SF-36 questionnaire.

\begin{tabular}{|c|c|c|c|}
\hline SF-36 & The pre-operative period & Postoperative & $\mathbf{P}$ \\
\hline Functional Capacity & 14.36 & 21.4 & $0.001^{*}$ \\
\hline Physical Limitation & 4.96 & 6.08 & 0.02 \\
\hline Pain & 5.04 & 7.24 & $0.009^{*}$ \\
\hline Overall health status & 14.56 & 17.96 & $0.007^{\star}$ \\
\hline Vitality & 11.96 & 16.52 & $0.001^{*}$ \\
\hline Social aspects & 6.32 & 7.84 & 0.025 \\
\hline Emotional Aspects & 3.88 & 5.6 & $0.0005^{\star}$ \\
\hline Mental Health & 16.44 & 23.24 & $0.001^{*}$ \\
\hline
\end{tabular}

but rather, to the maintenance of the presurgical angles

The pelvic incidence was defined as being a constant for each individual after growth and development, and determines the importance of essential elements of the spinopelvic system. ${ }^{4,8,11-13}$ Together with the pelvic incidence, the spinopelvic balance is determined by the sacral slope and pelvic variation. These variables differing according to the posture adopted, and together, are equivalent to the pelvic incidence. ${ }^{3.14}$ The lowest values considered normal for the angles of the pelvic incidence in an asymptomatic population are of approximately $35^{\circ}$, and the highest values are $85^{\circ}$, with an average of $51.9^{\circ} .{ }^{15}$

In our study the average value for the preoperative pelvic incidence was $59.88^{\circ}$. This shows that our sample of patients with degenerative disc disease had a slightly higher than average angulation, which was maintained in the postoperative measurement. On the other hand, after analysis of 30 patients with failure of conservative treatment and indication for surgery, Oliveira et al., in 2014 , obtained a mean $\mathrm{Pl}$ of $45^{\circ}$ that is below the average for the asymptomatic population. ${ }^{16-18}$

The Oswestry scale (Oswestry Disability Index - ODI) is an instrument for assessing the quality of life in disorders of the column by means of 10 clinical criteria with 6 answer alternatives each. It is used to access the degree of incapacity and the result after surgery. We obtained mean preoperative values of $46.2 \%$, which corresponds to severe inability, and mean postoperative values of $13.29 \%$, which corresponds to minimal incapacity, and a satisfactory post-surgical result $(p=0.00006)$. Comparing the results above, we observed a significant improvement in quality of life; this improvement is also seen in other studies reviewed in the literature. Ghizoni et al., ${ }^{17}$ obtained mean preoperative values of $72.3 \%$ and mean postoperative values of $51 \%$, with a reduction of $21.3 \%$ suggesting that surgical treatment of degenerative diseases of the lumbar spine resulted in a significant improvement in quality of life of the patients studied.

The SF-36 is a questionnaire that is used to evaluate quality of life. We observed, in the patients studied, a significant improvement in the different aspects of quality of life after surgery, ${ }^{6}$ with the exception of the areas of physical limitation and social aspects. Our results are similar to those of Gotfryd et al. ${ }^{18}$ who demonstrated that 22 patients who underwent lumbar arthrodesis presented good levels of quality of life, with the exception of the domain physical limitation.

Although surgeries for the treatment of lumbar diseases are becoming more common procedures in Brazil, due to the improved postoperative clinical support and the availability of less invasive techniques, they do not always show good results. Complex psychosocial issues, depression, and secondary gain are starting to be considered. ${ }^{1}$

Despite having a short follow-up time, our work suggests that the maintenance of angles of the patient without deformities of the spinopelvic junction is important for the success of surgery.

The fact that the work has a short follow-up period, and the lack of a control group, could be limiting factors when drawing possible conclusions. Another significant limitation is that no panoramic radiographs were used, despite the knowledge that this type of image is the gold standard for the calculation of sagittal balance. As we also observed, it was expected that the result for pelvic incidence would remain stable, as it is a stable index in adult patients.

\section{CONCLUSION}

It is concluded that despite some limitations, our initial results demonstrate that sacral slope, pelvic version and pelvic incidence do not change after the surgical procedure, with the preoperative values remaining relatively unchanged.

All authors declare no potential conflict of interest concerning this article. 
CONTRIBUTIONS OF THE AUTHORS: Each author made a significant individual contribution to the development of the manuscript. LC LR and $A B$ designed the project, and performed the revision of the data and the revision of the work, and performed the surgical procedures. RN, VSA, RMB and DCM conducted the enrolment and follow-up of patients, the inclusion and tabulation of the data, and the description and writing of the manuscript.

\section{REFERENCES}

1. Williams KD, Park AL. Lombalgia e transtornos dos discos intervertebrais. In: Canale ST, Beaty JH. Campbell's operative orthopedics. 11th ed. Philadelphia: Elsevier Mosby; 2007. p. 1955-62

2. Legaye, J, Hecquet J, Marty C, Duval-Beaupère G. Equilibre sagittal du rachis. Relations entre bassin et courbures rachidiennes sagittales en position debout. Rachis. 1993:5(5):215-26.

3. Mota H. O equilíbrio sagital da coluna vertebral nas doenças degenerativas [Internet]. 2010. Disponivel em: http://www.cursodequiropraxia.com.br/site/artigos/O_equilibrio_sagital_da_ coluna_vertebral_nas_doencas_degenerativas.pdf. (08/05/2015 20:15)

4. Radu ĀS. Hérnia Discal. In: Natour J. Coluna vertebral: conhecimentos básicos. São Paulo: Etcetera; 2004. p. 155-61.

5. Henneman SA, Antoneli PHL, Oliveira GC. Incidência pélvica: um parâmetro fundamental para definição do equilibrio sagital da coluna vertebral. Coluna/Columna. 2012:11(3): 237-39.

6. Liao JC, Chen WJ, Chen LH, Niu CC, Keorochana G. Surgical outcomes of degenerative spondylolisthesis with L5-S1 disc degeneration: comparison between lumbar floating fusion and lumbosacral fusion at a minimum 5-year follow-up. Spine (Phila Pa 1976). 2011;36(19):1600-07.

7. Suratwala SJ, Pinto MR, Gilbert TJ, Winter RB, Wroblewski JM. Functional and radiological outcomes of 360 degrees fusion of three or more motion levels in the lumbar spine for degenerative disc disease. Spine (Phila Pa 1976). 2009:34(10):E351-8.

8. During J, Goudfrooij H, Keessen W, Beeker TW, Crowe A. Toward standards for posture. Postural characteristics of the lower back system in normal and pathologic conditions. Spine (Phila Pa 1976). 1985;10(1):83-7.

9. Le Huec JC, Aunoble S, Philippe L, Nicolas P. Pelvic parameters: origin and significance. Eur Spine J. 2011;20(Suppl 5):564-71.

10. Bechara AHS, Zuiani GR, Risso Neto MI, Cavali PTM, Veiga IG, Pasqualini W, et al. Evolução dos Questionários Oswestry 2.0 e do componente físico (PCS) do SF-36 durante o primeiro ano do pós-operatório de artrodese da coluna lombar em doenças degenerativas. Coluna/ Columna. 2013;12(2): 128-32.

11. Vialle R, Levassor N, Rillardon L, Templier A, Skalli W, Guigui P. Radiographic analysis of the sagittal alignment and balance of the spine in asymptomatic subjects. J Bone Joint Surg Am. 2005;87(2):260-7.

12. Barrey C, Jund J, Noseda O, Roussouly P. Sagittal balance of the pelvis-spine complex and lumbar degenerative diseases. A comparative study about 85 cases. Eur Spine J 2007;16(9):1459-67.

13. Berthonnaud E, Dimnet J, Roussouly P, Labelle H. Analysis of the sagittal balance of the spine and pelvis using shape and orientation parameters. J Spinal Disord Tech. 2005:18(1):40-7.

14. Vaz G, Roussouly P, Berthonnaud E, Dimnet J. Sagittal morphology and equilibrium of pelvis and spine. Eur Spine J. 2002;11(1):80-7.

15. Roussouly P, Gollogly S, Berthonnaud E, Dimnet J. Classification of the normal variation in the sagittal alignment of the human lumbar spine and pelvis in the standing position. Spine (Phila $\mathrm{Pa}$ 1976). 2005;30(3):346-53.

16. Oliveira RP, Coimbra VG, Chisté YI, Batista Junior JL, Jacob Junior C, Cardoso IM, et al. Avaliação do equilibrio espinopélvico em pacientes submetidos a tratamento cirúrgico de hérnia de disco lombar. Rev Bras Ortop. 2014:49(2):189-93.

17. Ghizoni MF, Sakae TM, Felippe EBA, Souza BC, Danielli L, Padão DL. Aplicacão da escala de Oswestry em pacientes com doenca degenerativa da coluna lombar submetidos à artrodese. Oswestry em pacientes com doença degen

18. Gotfryd AO, Henriques GG, Polett PR. Influência da extensão da artrodese lombossacra nos resultados clínicos e funcionais. Coluna/Columna. 2012;11(1):13-6. 